\title{
Critical appraisal of ophthalmic ketorolac in treatment of pain and inflammation following cataract surgery
}

This article was published in the following Dove Press journal:

Clinical Ophthalmology

16 June 20II

Number of times this article has been viewed

\section{Rahul Reddy \\ Stephen Jae Kim}

Department of Ophthalmology, Vanderbilt University, Nashville, TN, USA
Correspondence: Stephen J Kim Vanderbilt Eye Institute, 23 II Pierce Avenue, Nashville, TN 37232, USA

Tel +I 6I59367126

Fax + I 615936 I540

Email skim30@gmail.com
Background: The purpose of this review was to provide a critical appraisal of the literature supporting the efficacy of ophthalmic ketorolac (Acuvail ${ }^{\circledR}$ ) in the treatment of pain and inflammation after cataract surgery.

Methods: Literature search and expert opinion of the authors.

Results: Recent studies indicate greater intraocular drug levels in the anterior chamber and iris-ciliary body after topical application of Acuvail in comparison with older formulations of ketorolac. A large randomized, multicenter, placebo-controlled study demonstrated significantly less inflammation and pain after cataract surgery using Acuvail.

Conclusion: Acuvail appears to be effective in reducing post-cataract surgery pain and inflammation.

Keywords: ketorolac tromethamine, Acuvail ${ }^{\circledR}$, postsurgical, cystoid macular edema, nonsteroidal anti-inflammatory drugs

\section{Introduction}

Inflammation frequently complicates intraocular surgery and can result in pain, elevated intraocular pressure, and cystoid macular edema (CME). ${ }^{1-3} \mathrm{CME}$ is the most common cause of vision loss after uncomplicated cataract surgery and although its pathogenesis remains incompletely understood, inflammation is a known cause. ${ }^{4}$ Excessive or persistent postoperative inflammation may also lead to prolonged compromise of the blood-ocular barrier and may increase the risk of chronic inflammation. Topical corticosteroids are effective for reducing and treating inflammation in the setting of cataract surgery, and have a long track record of ophthalmic use, but are limited by side effects, including elevated intraocular pressure, delayed wound healing, and increase risk of infection. Consequently, safer alternative anti-inflammatory agents to prevent and treat excessive postoperative inflammation and pain following cataract surgery would be advantageous.

Cyclo-oxygenase (COX) is an important enzyme in the inflammatory process and catalyzes the biosynthesis of prostaglandins and thromboxanes from arachidonic acid. ${ }^{1}$ Two main isoforms, COX-1 and COX-2, have been well characterized. COX-1 is constitutively expressed in most mammalian cells, including the kidney, gastrointestinal tract, platelets, and vascular endothelium, and plays a pivotal role in normal physiological function. COX-2, on the other hand, is an inducible enzyme that is thought to be primarily responsible for inflammatory-mediated reactions.

Nonsteroidal anti-inflammatory drugs (NSAIDs) are potent inhibitors of COX enzymes and thereby the synthesis of prostaglandins. While the anti-inflammatory 
actions of corticosteroids are in part from the inhibition of phospholipase $\mathrm{A}_{2}$ preventing the release of arachidonic acid from membrane-bound phospholipids, NSAIDs act more downstream in the cascade and directly inhibit COX-1 and COX-2 enzymes. Within the eye, it is firmly established that prostaglandins disrupt the blood-ocular barrier, increase vasodilation, facilitate leukocyte migration, and promote pain. ${ }^{1}$ Consequently, their inhibition should have favorable effects on both intraocular inflammation and pain.

In support of this, several randomized, prospective, double-masked, and placebo-controlled studies have shown that topically applied indomethacin $1 \%$, flurbiprofen $0.03 \%$, ketorolac $0.4 \%$ and $0.5 \%$, diclofenac $0.1 \%$, nepafenac $0.1 \%$, and bromfenac $0.09 \%$ reduce postoperative inflammation following cataract surgery. ${ }^{1}$ Similarly, prospective randomized studies have demonstrated that diclofenac $0.1 \%$, ketorolac $0.4 \%$, nepafenac $0.1 \%$, and bromfenac $0.09 \%$ reduce ocular discomfort after cataract surgery. ${ }^{1}$

Of all the commercially available ophthalmic NSAIDs, ketorolac tromethamine (ketorolac) possesses the greatest number of studies supporting its efficacy in preventing and treating postoperative inflammation and pain after cataract surgery (Table 1)..$^{5-21}$ Ketorolac $0.5 \%$ (Acular ${ }^{\circledR}$, Allergan Inc, Irvine, CA) is approved by the Food and Drug administration (FDA) for seasonal allergic conjunctivitis, inflammation following cataract surgery, and ocular discomfort after refractive surgery. ${ }^{22}$ To reduce the incidence of burning and stinging, a $0.4 \%$ concentration of ketorolac (Acular LS ${ }^{\circledR}$, Allergan Inc) was formulated, and appears to have a similar therapeutic effect. ${ }^{18,23}$ Ketorolac $0.4 \%$ is approved by the FDA for the reduction of ocular pain and burning following corneal refractive surgery. Both the $0.5 \%$ and $0.4 \%$ preparations are dosed four times daily. More recently, a preservative-free $0.45 \%$ preparation of ketorolac (Acuvail ${ }^{\circledR}$, Allergan Inc) in carboxymethylcellulose was approved by the FDA in 2009 for the treatment of pain and inflammation following cataract surgery and is dosed twice daily. ${ }^{24}$ The specific intent of this review is to assess the available evidence supporting the efficacy of Acuvail in the treatment of pain and inflammation after cataract surgery.

\section{Pharmacology of ketorolac}

NSAIDs are a chemically heterogenous group of compounds that inhibit the formation of prostaglandins and lack a steroid nucleus biosynthetically derived from cholesterol. There are six major classes, but topical formulations are limited to the relatively water-soluble classes, ie, indole acetic, aryl acetic, and aryl propionic acids. ${ }^{25}$
Ketorolac tromethamine is an aryl acetic acid derivative. The chemical name is $( \pm)$-5-benzoyl-2,3- dihydro- $1 \mathrm{H}$ pyrrolizine-1-carboxylic acid, compounded with 2-amino2-(hydroxymethyl)-1,3-propanediol (1:1). The molecular weight is 376.41 and the molecular formula is $\mathrm{C}_{19} \mathrm{H}_{24} \mathrm{~N}_{2} \mathrm{O}_{6}$. Current preparations consist of a racemic mixture of $\mathrm{R}-(+)$ and S-(-) ketorolac tromethamine.

When administered systemically, ketorolac has proven analgesic, anti-inflammatory, and antipyretic activity. ${ }^{1}$ Its mechanism of action, as with all NSAIDs, is presumed to be due to inhibition of prostaglandin biosynthesis. However, systemic administration is not thought to achieve sufficient intraocular drug levels to inhibit prostaglandin synthesis completely in the ciliary body and iris. ${ }^{1}$ Topical administration of ketorolac, on the other hand, reaches adequate levels to inhibit prostaglandin synthesis in these target tissues. In one study, after a single topical application of ketorolac $0.4 \%$, a peak aqueous concentration of $57.5 \mathrm{ng} / \mathrm{mL}$ was achieved after 60 minutes. ${ }^{26}$ Another study demonstrated mean aqueous concentration of $1079 \mathrm{ng} / \mathrm{mL}$ after a total of 12 doses of ketorolac $0.4 \%$ administered over 2 days. ${ }^{27}$

The original ophthalmic formulation of ketorolac is a $0.5 \%$ solution marketed as Acular. A $0.4 \%$ formulation (Acular LS) was introduced in the US in 2003 . The $0.5 \%$ and $0.4 \%$ preparations are supplied as an isotonic aqueous mixture with a $\mathrm{pH}$ of 7.4, and have an osmolality of approximately $290 \mathrm{mOsmol} / \mathrm{kg}$. However, both the $0.4 \%$ and $0.5 \%$ solutions contain benzalkonium chloride (a preservative), the surfactant octoxynol-40, and sodium edetate (a metalchelating agent), and are associated with a high incidence of burning and stinging on instillation (as high as 40\%). . $22,23,28^{2}$

In an effort to increase ocular bioavailability, a new formulation of ketorolac was developed to preserve the efficacy of prior formulations, while enhancing tolerability with a less frequent dosing regimen. ${ }^{21}$ Compared with the ketorolac $0.4 \%$ formulation, the concentration of Acuvail is $12 \%$ greater $(0.45 \%)$ and carboxymethylcellulose is added to the emulsion to allow greater drug retention on the ocular surface and improve comfort and drug penetration. Other key changes include lower $\mathrm{pH}$ and absence of surfactant, metal-chelating agents, and preservatives. As such, Acuvail is supplied as a sterile isotonic preservativefree solution with a $\mathrm{pH}$ and osmolality of approximately 6.8 and $285 \mathrm{mOsmol} / \mathrm{kg}$, respectively, and is approved by the FDA for treatment of pain and inflammation following cataract surgery.

In a study by Attar et al evaluating the pharmacokinetics of ketorolac $0.45 \%$ versus $0.4 \%$, the addition of carboxymethylcellulose in combination with the $12 \%$ increase in concentration 
Table I Clinical studies with ketorolac in post-cataract surgery inflammation and pain

\begin{tabular}{|c|c|c|c|c|c|c|c|}
\hline Author & Year & Patients/Eyes & Ketorolac & Dosing regimen & $P=$ cells $/$ flare & $\mathbf{P}=$ pain & Conclusions \\
\hline El Harazi et $\mathrm{al}^{5}$ & 1988 & $58 \mathrm{pts}$ & $0.50 \%$ & $\begin{array}{l}4 \times \text { daily I wk then } \\
\text { BID } \times 3 \text { wks }\end{array}$ & & & $\begin{array}{l}\text { Ketorolac }= \\
\text { diclofenac }= \\
\text { prednisolone } 1 \% \text { for } \\
\text { inflammation }\end{array}$ \\
\hline Flach et $\mathrm{al}^{6}$ & 1988 & $118 \mathrm{pts}$ & $0.50 \%$ & I gtt $3 \times$ daily & 0.001 & & $\begin{array}{l}\text { Ketorolac }>\text { placebo } \\
\text { for inflammation }\end{array}$ \\
\hline Flach et $\mathrm{al}^{7}$ & 1989 & $127 \mathrm{pts}$ & $0.50 \%$ & $\begin{array}{l}\text { Pre and } \\
\text { postoperatively }\end{array}$ & 0.53 & & $\begin{array}{l}\text { Ketorolac = } \\
\text { dexamethasone for } \\
\text { inflammation }\end{array}$ \\
\hline Ostrov et $\mathrm{al}^{8}$ & 1997 & $157 \mathrm{pts}$ & $0.50 \%$ & $\begin{array}{l}\text { I day preop and } \\
4 \text { wks postop }\end{array}$ & & & $\begin{array}{l}\text { Ketorolac = } \\
\text { prednisone } 1 \%= \\
\text { dexamethasone for } \\
\text { inflammation }\end{array}$ \\
\hline Heier et $\mathrm{al}^{9}$ & 1999 & 102 pts & $0.50 \%$ & $4 \times$ daily & $0.030 / 0.025$ & 0.049 & $\begin{array}{l}\text { Ketorolac }>\text { placebo } \\
\text { for inflammation and } \\
\text { pain }\end{array}$ \\
\hline Simone et $\mathrm{a}^{10}$ & 1999 & 59 pts & $0.50 \%$ & $\begin{array}{l}\text { I to } 2 \text { drops } \\
4 \text { times daily } \times \\
\text { I wk then tapered }\end{array}$ & & & $\begin{array}{l}\text { Ketorolac = } \\
\text { prednisolone } 1 \% \text { for } \\
\text { inflammation and pain }\end{array}$ \\
\hline Snyder et al ${ }^{\prime \prime}$ & 2000 & 26 pts & $0.50 \%$ & $\begin{array}{l}\text { Pre and } \\
\text { postoperatively }\end{array}$ & & & $\begin{array}{l}\text { Ketorolac = } \\
\text { flurbiprofen/ } \\
\text { prednisolone I\% for } \\
\text { inflammation }\end{array}$ \\
\hline Soloman et $\mathrm{al}^{12}$ & 2001 & 104 eyes & $0.50 \%$ & $\begin{array}{l}4 \times \text { daily starting } \\
24 \text { hrs after surgery }\end{array}$ & $0.0002 / 0.00 \mathrm{I}$ & 0.043 & $\begin{array}{l}\text { Ketorolac }>\text { placebo } \\
\text { for inflammation }\end{array}$ \\
\hline Soloman et $\mathrm{al}^{13}$ & 2001 & $36 \mathrm{pts}$ & $0.50 \%$ & $\begin{array}{l}4 \times \text { daily starting } \\
24 \mathrm{hrs} \text { after surgery }\end{array}$ & $0.17 / 0.48$ & & $\begin{array}{l}\text { Ketorolac = } \\
\text { rimexolone I\% for } \\
\text { cell/flare }\end{array}$ \\
\hline Holzer et al ${ }^{14}$ & 2002 & $60 \mathrm{pts}$ & $0.50 \%$ & $\begin{array}{l}4 \text { times a day } \times I \text { wk } \\
\text { then BID } \times 3 \text { wks }\end{array}$ & & & $\begin{array}{l}\text { Ketorolac = } \\
\text { loteprednol for } \\
\text { inflammation }\end{array}$ \\
\hline Trinivarat et al ${ }^{15}$ & 2003 & $120 \mathrm{pts}$ & $0.50 \%$ & $4 \times$ daily & 0.008 & & $\begin{array}{l}\text { Prednisolone }> \\
\text { ketorolac for } \\
\text { inflammation }\end{array}$ \\
\hline Price and Price ${ }^{16}$ & 2004 & 25 pts ( 50 eyes) & $0.40 \%$ & $\begin{array}{l}4 \times \text { daily starting } \\
3 \text { days prior and } \\
\text { I day after } C E\end{array}$ & & 0.02 & $\begin{array}{l}\text { Ketorolac }>\text { placebo } \\
\text { for pain }\end{array}$ \\
\hline Donnenfeld et al ${ }^{17}$ & 2006 & 4 grps of 25 & $0.40 \%$ & $\begin{array}{l}4 \text { times daily } \\
\text { pre and post } \\
\text { operatively }\end{array}$ & 0.001 & 0.001 & $\begin{array}{l}\text { Preoperative } \\
\text { ketorolac decreased } \\
\text { inflammation }\end{array}$ \\
\hline Sandoval et al ${ }^{18}$ & 2006 & 40 eyes total & $0.4 \% / 0.5 \%$ & $\begin{array}{l}4 \times \text { daily } \times I \text { wk } \\
\text { then BID } \times 3 \text { wks }\end{array}$ & & & $\begin{array}{l}\text { Comparative study } \\
\text { revealed } 0.5 \%> \\
\text { stinging/burning }\end{array}$ \\
\hline Duong et al ${ }^{19}$ & 2007 & 193 eyes & $0.40 \%$ & $4 \times$ daily & 0.33 & 0.025 & $\begin{array}{l}\text { Ketorolac }> \\
\text { nepafenac for pain }\end{array}$ \\
\hline Maca et $\mathrm{a}^{20}$ & 2010 & $100 \mathrm{pts}$ & $0.50 \%$ & $4 \times$ daily & & 0.001 & $\begin{array}{l}\text { Diclofenac = } \\
\text { ketorolac for } \\
\text { inflammation }\end{array}$ \\
\hline Donnenfeld et $\mathrm{a}^{21}$ & 2011 & $5 \mathrm{Il}$ pts & $0.45 \%$ & $2 \times$ daily & 0.001 & 0.001 & $\begin{array}{l}\text { Ketorolac }> \\
\text { placebo for pain and } \\
\text { inflammation }\end{array}$ \\
\hline
\end{tabular}

resulted in a $35 \%$ enhancement of bioavailability in the aqueous humor of the $0.45 \%$ preparation. ${ }^{29}$ Furthermore, decreasing the $\mathrm{pH}$ from 7.4 to 6.8 in combination with addition of carboxymethylcellulose enhanced bioavailability in the aqueous humor by two-fold and in the iris-ciliary body by three-fold.
At the time of writing, the pharmacokinetics of Acuvail have not been assessed in humans, but both Acular LS and Acuvail formulations were directly compared after a single topical application of $35 \mu \mathrm{L} .{ }^{29}$ Peak concentration in the aqueous humor and iris-ciliary body was $389 \mathrm{ng} / \mathrm{mL}$ and $450 \mathrm{ng} / \mathrm{g}$, 
respectively, for Acuvail, and $211 \mathrm{ng} / \mathrm{mL}$ and $216 \mathrm{ng} / \mathrm{g}$, respectively, for Acular LS. This study concluded that Acuvail delivered significantly higher concentrations of ketorolac to the aqueous humor and iris-ciliary body. Waterbury et al directly compared the peak and trough intraocular levels of Acuvail, bromfenac $0.9 \%$ (Xibrom ${ }^{\circledR}$, ISTA Pharmaceuticals Inc, Irvine, CA), and placebo after three applications $(35 \mu \mathrm{L})$ every 20 minutes in an animal model of lipopolysaccharideinduced inflammation. ${ }^{30}$ Peak concentrations in the aqueous humor and iris-ciliary body were $738 \mathrm{ng} / \mathrm{mL}$ and $556 \mathrm{ng} / \mathrm{g}$, respectively, for Acuvail and $94 \mathrm{ng} / \mathrm{mL}$ and $46 \mathrm{ng} / \mathrm{g}$, respectively, for bromfenac $0.9 \%$. Trough concentrations in the aqueous humor and iris-ciliary body were $127 \mathrm{ng} / \mathrm{mL}$ and $59 \mathrm{ng} / \mathrm{g}$, respectively, for Acuvail, and $17 \mathrm{ng} / \mathrm{mL}$ and $8 \mathrm{ng} / \mathrm{g}$, respectively, for bromfenac $0.9 \%$. The study concluded that Acuvail achieved aqueous and iris-ciliary body concentrations that exceeded its inhibitory concentration of $50 \%\left(\mathrm{IC}_{50}\right)$ values for COX-1 and COX-2 at both peak and trough (Table 2). ${ }^{1,26,31,32}$ In addition, while both NSAIDs inhibited lipopolysaccharideinduced aqueous prostaglandin $\mathrm{E}_{2}$ elevation, only Acuvail significantly prevented vascular leakage, as measured by fluorescein isothiocyanate-dextran leakage at trough levels.

Although suggestive, the number of animals used in both studies was small, and therefore additional studies with larger sample sizes are needed to confirm these initial results. Furthermore, both studies used New Zealand white rabbits which lack pigment, blink infrequently, and have an unusually unstable blood-aqueous barrier, so these results should be extrapolated to humans with caution.

Given the favorable pharmacokinetic data of Acuvail, approval was granted for twice-daily dosing in contrast with four times daily dosing for Acular LS. This reduced dosing regimen offers a distinct therapeutic advantage for Acuvail because in addition to patient convenience, several studies have suggested increased patient compliance with less frequent dosing. ${ }^{33}$

\section{Efficacy studies}

The efficacy of Acuvail was assessed in two identical multicenter, double-masked, randomized, placebo-controlled,

Table 2 Reported ranges of $\mathrm{IC}_{50}$ for COX-I and COX-2 of ocular NSAIDs

\begin{tabular}{lll}
\hline Drug & COX-I IC I0 $_{50} \mu \mathrm{m}(\mathrm{ng} / \mathrm{mL})$ & COX-2 IC $_{50} \mu \mathrm{m}(\mathrm{ng} / \mathrm{mL})$ \\
\hline Amfenac & 0.14 to $0.25(35.6$ to 63.6$)$ & 0.002 to $0.15(0.5$ I to $38 . I)$ \\
Diclofenac & 0.12 to $0.95(38$ to 302.1$)$ & 0.03 to $0.09(9.5$ to 28.6$)$ \\
Ketorolac & 0.014 to $0.02(5.3$ to 7.5$)$ & 0.09 to $0.12(33.9$ to 45.2$)$ \\
Bromfenac & 0.09 to $0.53(3.4$ to 203.1$)$ & 0.007 to $0.023(2.7$ to 8.8$)$ \\
\hline
\end{tabular}

Abbreviations: COX, cyclooxygenase; $I C_{50}$, half-maximum inhibition relative to control values. parallel studies and specifically conducted to evaluate the effects of Acuvail on relief of pain and inflammation after cataract surgery. ${ }^{21}$ The results of these parallel studies were analyzed together and collectively involved 511 patients.

Patients were randomized in a 2:1 ratio to receive either Acuvail or vehicle in the operative eye for 16 days. Patients were dosed twice daily the day before surgery. On the day of surgery, patients had one drop upon awakening, three drops each 20 minutes apart starting two hours before surgery, one drop before discharge, and one drop 12 hours after the first dose upon awakening, resulting in a total of six drops of the study medication. Patients continued one drop twice daily of the study medication for 14 days after surgery. No patients were exposed to topical corticosteroids during the study period.

All patients underwent elective unilateral, uncomplicated, extracapsular cataract extraction with posterior chamber intraocular lens implantation. Patients were evaluated on postoperative days $1,3,7$, and 14 . The primary efficacy endpoint was the percentage of patients with a summed ocular inflammation score (SOIS) of 0 for anterior chamber cell and flare on day 14 . The main secondary efficacy endpoint was the percentage of patients with no pain (grade $=0$ ) on postoperative day 1 .

In this study, anterior chamber cell was graded on a six-point scale and anterior chamber flare was graded on a five-point scale. The SOIS was calculated as the sum of scores for anterior chamber cell and flare. To assess the degree of pain, patients called an interactive voice response system diary twice daily during the two weeks after the day of surgery and were instructed to rate their level of ocular pain on a five-point scale $(0=$ none, $1=$ mild, $2=$ moderate, 3 = severe, $4=$ intolerable).

The Acuvail group had a significantly higher percentage of patients with a SOIS score of 0 compared with vehicle at days 7 and 14. At day 7, Acuvail and vehicle had a SOIS score of 0 for $32 \%(102 / 318)$ and $17 \%$ (26/155) of patients, respectively $(P<0.001)$. At day 14 , Acuvail and vehicle had a SOIS score of 0 for 53\% (167/318) and 27\% (41/155) of patients, respectively $(P<0.001)$.

Acuvail was also significantly superior to vehicle in resolving ocular pain after cataract surgery. A pain score of 0 on day 1 was reported in $72 \%(233 / 322)$ of Acuvail patients versus $40 \%(62 / 156)$ in vehicle patients $(P<0.001)$. The median time to postoperative ocular pain resolution was one day in patients treated with Acuvail and two days in patients treated with vehicle $(P<0.001)$.

Although the combined results of these controlled studies demonstrate the efficacy of Acuvail for the prevention and 
treatment of postoperative inflammation and pain after cataract surgery, these results should be interpreted with caution. The importance of achieving a median of one less day of pain with Acuvail versus placebo needs to be assessed in the appropriate context of treatment cost, clinical impact, and in the absence of concomitant corticosteroid use. Moreover, cell and flare were combined together in contrast with grading each outcome independently, and their summation may have amplified the treatment differences observed between the Acuvail and vehicle group. In addition, because corticosteroids were not used concomitantly, no information can be discerned about the additive benefits of Acuvail with a corticosteroid in regards to inflammation and pain following cataract surgery. In a study comparing the efficacy of ketorolac $0.5 \%$ with prednisolone acetate $1 \%$, Simone et al observed that prednisolone acetate was more effective at reducing intraocular inflammation by day 7 after cataract surgery than ketorolac, although this difference resolved by day 28. ${ }^{10}$ Several studies have demonstrated an additive benefit of a topical NSAID with a corticosteroid and their combined use, therefore, is common in clinical practice. ${ }^{1}$ Therefore, the results of this study cannot be directly applied in the setting of concomitant corticosteroid use. Nevertheless, previous studies have demonstrated an additive benefit of ketorolac $0.5 \%$ or $0.4 \%$ when used in conjunction with corticosteroids in reducing inflammation, pain, and CME following cataract surgery. Thus, given the favorable pharmacokinetics of Acuvail in comparison with these older formulations, similar therapeutic benefit may be likely. ${ }^{5-21}$

\section{Selective COX-I versus COX-2 inhibition}

Several in vitro studies indicate that ketorolac is the most potent inhibitor of COX-1, while both amfenac (active component in $\mathrm{Nevanac}^{\circledR}$, Alcon Laboratories Inc, Fort Worth, TX) and bromfenac have been reported as being the most potent inhibitors of COX-2. ${ }^{1,26,31,32}$ Bromfenac may be a 3-18 times more potent inhibitor of COX-2 than diclofenac, amfenac, and ketorolac. ${ }^{25,32}$ Another study found that amfenac was a more potent inhibitor of COX-2 than bromfenac. Differences in experimental testing and design may explain these conflicting findings. COX-2 is an inducible enzyme and is thought to be primarily responsible for inflammation. Therefore, the anti-inflammatory actions of NSAIDs are presumed to relate to their ability to inhibit this isoform. However, this paradigm has not been consistently demonstrated in clinical trials, and the possibility exists that COX-1 also plays an important role in inflammation and, in the presence of substrate, may readily convert arachidonic acids into prostaglandins. Thus, the clinical importance of selective COX-1 versus COX-2 inhibition for ocular disease remains unproven.

Although ketorolac is approximately six times more potent as an inhibitor of COX-1 than COX-2 (Table 2), it is nevertheless a potent inhibitor of COX-2, with an $\mathrm{IC}_{50}$ in the range of $0.09-0.12 \mu \mathrm{M}(33.9-45.2 \mathrm{ng} / \mathrm{mL}) .{ }^{32}$ This allows ketorolac to inhibit COX-2 in the iris-ciliary body after topical application, an important fact that can be overlooked if the relative COX-1/COX-2 potencies of ocular NSAIDs are emphasized. On the other hand, ketorolac is an approximately 5-50 times more potent inhibitor of COX-1 than diclofenac, bromfenac, and amfenac. The ability to inhibit both isoforms of COX for short periods of time may be advantageous in allowing more rapid and complete inhibition of prostaglandin production, but long-term inhibition of COX-1 may not be desirable because it is involved in normal physiologic function.

\section{NSAIDs and corticosteroids}

The combination use of topical NSAIDs and corticosteroids is sometimes referred to as "synergistic" in the literature. This clinical impression of synergy remains unproven and would seem unlikely, given the fact that both drug classes inhibit prostaglandin production (Figure 1). Synergy is defined, in general, as two or more agents working in combination to produce an effect that could not be obtained by each agent independently. A classic example of synergy involves penicillin and aminoglycoside antibiotics where use of both antibiotics in combination significantly lowers the $\mathrm{IC}_{50}$ of each antibiotic for a given organism. Although a large, randomized, prospective study demonstrated that ketorolac $0.5 \%$ was more effective than dexamethasone sodium phosphate $0.1 \%$

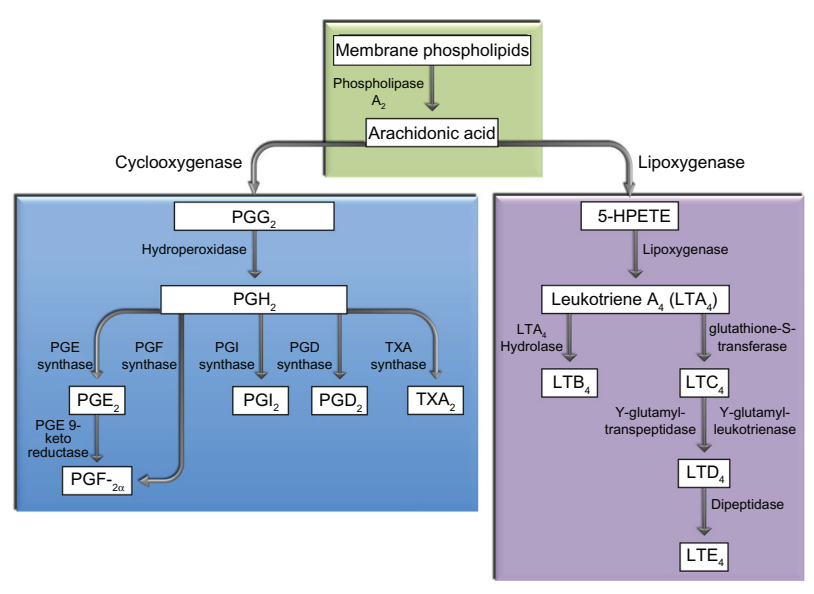

Figure I Corticosteroids inhibit phospholipase $A_{2}$ while nonsteroidal antiinflammatory drugs act more downstream and directly inhibit cyclo-oxygenase. 
solution in facilitating re-establishment of the blood-aqueous barrier after surgery, differences in drug formulation and intraocular concentration preclude any conclusions about synergy. ${ }^{34-36}$ Furthermore, although many prospective studies have confirmed that the combination use of an NSAID and corticosteroid is superior to a corticosteroid alone for pain, inflammation, CME, and visual improvement after intraocular surgery, these findings can be explained by an additive effect of a second anti-inflammatory agent. ${ }^{1,17,37}$ The distinction between a synergistic effect and an additive effect has important implications because synergy implies that an NSAID used in combination with a corticosteroid provides a therapeutic effect that cannot be replicated by simply increasing the dosing regimen of the corticosteroid.

\section{Ketorolac and posterior segment disease}

Although topical administration of NSAIDs provides aqueous humor levels adequate to suppress prostaglandin synthesis in the iris and ciliary body, the ability to suppress prostaglandin synthesis in the retina/choroid is less certain. In an animal model, ketorolac $0.5 \%$ could not be detected in the vitreous after topical administration, but in a small prospective comparative study of patients undergoing vitrectomy, ketorolac $0.4 \%$ could be detected in the vitreous $(2.8 \mathrm{ng} / \mathrm{mL})$ and reduced vitreous prostaglandin $\mathrm{E}_{2}$ levels. ${ }^{38,39}$ This observed reduction was presumably from inhibition of iris and ciliary body prostaglandin $\mathrm{E}_{2}$ production because the measured vitreous concentration of ketorolac was considerably less than the $\mathrm{IC}_{50}$ for both COX-1 and COX-2 inhibition, and therefore unlikely to have inhibited COX activity in retinal cells.

Accumulating evidence indicates that COX-2 has important implications for retinal disease. ${ }^{1,40} \mathrm{COX}-2$ is the predominant isoform in human retinal pigment epithelial cells and is significantly upregulated in response to proinflammatory cytokines. ${ }^{41} \mathrm{COX}-2$ is also present in choroidal neovascularization, as well as in other highly vascularized lesions, and its expression increases in diabetic retinopathy. ${ }^{1,42}$ In a variety of experimental systems, COX-2 inhibition suppresses angiogenesis. ${ }^{43}$ In this regard, both nepafenac $0.1 \%$ and bromfenac $0.09 \%$ could be detected in the rabbit retina after topical administration, and in one study nepafenac inhibited $55 \%$ of retinal prostaglandin synthesis. ${ }^{31,44}$ In another study, topical ketorolac $0.4 \%$ inhibited experimentally induced choroidal neovascularization and reduced both retinal prostaglandin $\mathrm{E}_{2}$ and vascular endothelial growth factor levels by $>30 \%{ }^{45}$ While interesting, these results were obtained in animal models and cannot be directly extrapolated to humans. Given the favorable pharmacokinetics of Acuvail versus Acular LS, it is worth speculating that clinically meaningful retinal COX inhibition may now be achievable.

\section{Safety and tolerability}

The overall incidence of treatment-related adverse events was significantly higher in the vehicle group (14\%) than in the Acuvail group (6\%). ${ }^{21}$ The most common adverse events reported were increased intraocular pressure, conjunctival hyperemia, and/or hemorrhage, corneal edema, ocular pain, headache, tearing, and blurred vision. The most common adverse events reported at a higher frequency than vehicle included increased intraocular pressure $(5.8 \%$ versus $1.8 \%)$, conjunctival hemorrhage $(1.2 \%$ versus $0.6 \%)$, and blurred vision $(1.2 \%$ versus $0.6 \%)$, and were generally considered by the clinical investigators to be a consequence of the cataract procedure. Adverse events of burning and stinging were low, with only $1.5 \%$ of patents in the Acuvail group and $0.6 \%$ in the vehicle group reporting such an occurrence.

When ketorolac $0.5 \%$ was topically applied in one eye three times daily, only five of 26 subjects had a detectable amount of ketorolac in their plasma (range 10.7-22.5 ng/mL) at day 10 . In contrast, when ketorolac $10 \mathrm{mg}$ was administered systemically every six hours, peak plasma levels were around $960 \mathrm{ng} / \mathrm{mL}$. Given the possibility of systemic absorption after topical application, techniques such as lid closure and nasolacrimal occlusion may be used to decrease systemic exposure.

As with other NSAIDs, Acuvail may slow or delay healing, and in some susceptible patients, continued use of topical NSAIDs may result in epithelial breakdown, corneal thinning, corneal erosion, corneal ulceration, or corneal perforation. There exists the potential for cross-sensitivity to acetylsalicylic acid, phenylacetic acid derivatives, and other NSAIDs, and therefore caution should be used when treating individuals who have previously exhibited sensitivities to these drugs. NSAIDs interfere with thrombocyte aggregation and may prolong bleeding time. Therefore, it is recommended that topical NSAIDs be used with caution in patients with known bleeding tendencies or who are receiving anticoagulation.

There are no adequate well controlled studies of topical NSAIDs in pregnant woman and, as such, these medications are classified as Category C. Because of the known effects of prostaglandin-inhibiting drugs on the fetal cardiovascular system (closure of the ductus arteriosus), the use of topical NSAIDs should be avoided during late pregnancy. 
Severe corneal toxicity has been reported with diclofenac $0.1 \%$, ketorolac $0.5 \%$, nepafenac $0.1 \%$, and bromfenac $0.09 \% .{ }^{1}$ Although uncommon, these dramatic events are referred to as corneal melt. However, a definite link between NSAID use and corneal melt remains unproven, but it is still prudent to avoid NSAID use in patients with severe corneal surface disease.

\section{Patient satisfaction}

There are limited data on patient satisfaction with Acuvail. Older formulations of ketorolac had an incidence of transient burning and stinging on instillation of approximately $20 \%-40 \%$ for the $0.4 \%$ concentration and $40 \%$ for the $0.5 \%$ concentration. ${ }^{22,23}$ In contrast, Acuvail was associated with substantially lower rates (1.5\%) of burning and stinging. ${ }^{21}$

Most importantly, a significantly higher percentage of patients randomized to Acuvail had a 3-line or more improvement in vision from baseline compared with those treated with vehicle. ${ }^{21}$ At least two previously published studies using ketorolac $0.4 \%$ demonstrated a similar beneficial effect upon visual acuity following cataract and vitreoretinal surgery. ${ }^{17,37}$ In patients undergoing routine vitreoretinal surgery, patients randomized to ketorolac $0.4 \%$ experienced an average 4.3-line improvement from baseline compared with a 2.5 -line improvement with placebo. ${ }^{37}$ This greater improvement in vision in the ketorolac group was observed despite concomitant corticosteroid use in both groups.

\section{Conclusion}

Excessive postoperative inflammation and pain after cataract surgery can delay visual recovery and affect long-term outcomes. There is substantial evidence from well designed studies with sufficient numbers of patients that ketorolac formulations $0.4 \%$ and $0.5 \%$ effectively treat both inflammation and pain after cataract surgery. Recent evidence indicates that Acuvail possesses similar therapeutic benefit. Given the favorable pharmacokinetics, better tolerance, and reduced dosing requirement of Acuvail, additional clinical studies comparing Acuvail with other NSAIDs for the treatment of inflammation and pain after cataract surgery are indicated to confirm these promising results.

\section{Acknowledgment}

Supported by an unrestricted grant from Research to Prevent Blindness to the Department of Ophthalmology and Visual Sciences, Vanderbilt University School of Medicine.

\section{Disclosure}

SJK is a consultant for Ophthotech. RR declares no conflicts of interest in this work.

\section{References}

1. Kim SJ, Flach AJ, Jampol LE. Nonsteroidal anti-inflammatory drugs in ophthalmology. Surv Ophthalmol. 2010;55(2):108-133.

2. Kim SJ, Bressler NM. Optical coherence tomography and cataract surgery. Curr Opin Ophthalmol. 2009;20(1):46-51.

3. Kim SJ, Equi R, Bressler NM. Analysis of macular edema after cataract surgery in patients with diabetes using optical coherence tomography. Ophthalmology. 2007;114(5):881-889.

4. Belair ML, Kim SJ, Thorne JE, et al. Incidence of cystoid macular edema after cataract surgery in patients with and without uveitis using optical coherence tomography. Am J Ophthalmol. 2009;148(1): 128-135.

5. El Harazi SM, Ruiz RS, Feldman RM, Villanueva G, Chuang AZ. A randomized double-masked trial comparing ketorolac tromethamine $0.5 \%$, diclofenac sodium $0.1 \%$, and prednisolone acetate $1 \%$ in reducing post-phacoemulsification flare and cells. Ophthalmic Surg Lasers. 1988;29(7):539-544.

6. Flach AJ, Lavelle CJ, Olander KW, Retzlaff JA, Sorenson LW. The effect of ketorolac tromethamine $0.5 \%$ in reducing postoperative inflammation after cataract extraction and intraocular lens implantation. Ophthalmology. 1988;95(9):1279-1284.

7. Flach AJ, Jaffe NS, Akers WA. The effect of ketorolac tromethamine in reducing postoperative inflammation: Double-mask parallel comparison with dexamethasone. Ann Ophthalmol. 1989;21(11):407-411.

8. Ostrov CS, Sirkin SR, Deutsch WE, Masi RJ, Chandler JW, Lindquist TD. Ketorolac, prednisolone, and dexamethasone for postoperative inflammation. Clin Ther. 1997;19(2):259-272.

9. Heier J, Cheetham JK, Degryse R, et al. Ketorolac tromethamine $0.5 \%$ ophthalmic solution in the treatment of moderate to severe ocular inflammation after cataract surgery: A randomized vehicle-controlled clinical trial. Am J Ophthalmol. 1999;27(3):253-259.

10. Simone JN, Pendelton RA, Jenkins JE. Comparison of the efficacy and safety of ketorolac tromethamine $0.5 \%$ and prednisolone acetate $1 \%$ after cataract surgery. J Cataract Refract Surg. 1999;25(5): 699-704.

11. Snyder RW, Siekert RW, Schwiegerling J, Donnenfeld E, Thompson P. Acular as a single agent for use as an anti-miotic and anti-inflammatory in cataract surgery. J Cataract Refract Surg. 2000;26(8):1225-1227.

12. Solomon KD, Vroman DT, Barker D, Gehiken J. Comparison of ketorolac tromethamine $0.5 \%$ and rimexolone $1 \%$ to control inflammation after cataract extraction; prospective, randomized, double masked study. J Cataract Refract Surg. 2001;27(1):232-237.

13. Solomon KD, Cheetham JK, DeGryse R, Brint SF, Rosenthal A. Topical ketorolac tromethamine $0.5 \%$ ophthalmic solution in ocular inflammation after cataract surgery. Ophthalmology. 2001;108(2):331-337.

14. Holzer MP, Solomon KD, Sandoval HP, Vroman DT. Comparison of ketorolac tromethamine $0.5 \%$ and loteprednol etabonate $0.5 \%$ for the treatment of inflammation following phacoemulsification: A prospective, randomized, double-masked study. J Cataract Refract Surg. 2002;28(1):93-99.

15. Trinivarat A, Atchaneeyasakul LO, Surachatkumtonekul T, Kosrirukvongs P. Comparison of topical prednisolone acetate, ketorolac tromethamine and fluorometholone acetate in reducing inflammation after phacoemulsification. $J$ Med Assoc Thai. 2003;86(2):143-150.

16. Price MO, Price FW. Efficacy of topical ketorolac tromethamine $0.4 \%$ for control of pain or discomfort associated with cataract surgery. Curr Med Res Opin. 2004;20(12):2015-2019.

17. Donnenfeld ED, Perry HD, Wittipen JR, Solomon R, Chou T. Preoperative ketorolac tromethamine $0.4 \%$ in phacoemulsification outcomes: Pharmacokinetic-response curve. J Cataract Refract Surg. 2006;32(9):1474-1482.

18. Sandoval HP, De Castro LE, Vroman DT, Solomon KD. Evaluation of $0.4 \%$ ketorolac tromethamine ophthalmic solution versus $0.5 \%$ ketorolac tromethamine ophthalmic solution after phacoemulsification and intraocular lens implantation. J Ocul Pharmacol Ther. 2006;22(4):251-257. 
19. Duong HV, Westfield KC, Chalkley TH. Ketorolac tromethamine LS $0.4 \%$ versus nepafenac $0.1 \%$ in patients having cataract surgery. Prospective randomized double-masked clinical trial. J Cataract Refract Surg. 2007;33(11):1925-1929.

20. Maca SM, Amon M, Findi O, Kahraman G, Barisani-Asenbauer T. Efficacy and tolerability of preservative free and preserved diclofenac and preserved ketorolac eyedrops after cataract surgery. Am J Ophthalmol. 2010;149(5):777-784.

21. Donnenfeld ED, Nichamin LD, Hardten DR, et al. Twice-daily, preservative-free ketorolac $0.45 \%$ for treatment of inflammation and pain after cataract surgery. Am J Ophthalmol. 2011;151(3):420-426.

22. Acular [Package insert]. Irvine, CA: Allergan Inc; 1997.

23. Acular LS [Package insert]. Irvine, CA: Allergan Inc; 2008.

24. Acuvail [Package insert]. Irvine, CA: Allergan Inc; 2009.

25. Ahuja M, Dhake AS, Sharma SK, Majumdar DK. Topical ocular delivery of NSAIDs. AAPS J. 2008;10(2):229-241.

26. Walters T, Raizman M, Ernest $P$, et al. In vivo pharmacokinetics and in vitro pharmacodynamics of nepafenac, amfenac, ketorolac, and bromfenac. J Cataract Refract Surg. 2007;33(9):1539-1545.

27. Bucci FA Jr, Waterbury LD, Amico LM. Prostaglandin $\mathrm{E}_{2}$ inhibition and aqueous concentration of ketorolac $0.4 \%$ (Acular LS) and nepafenac $0.1 \%$ (Nevanac) in patients undergoing phacoemulsification. Am J Ophthalmol. 2007;144(1):146-147.

28. Solomon KD, Donnenfeld ED, Raizman M, et al. Safety and efficacy of ketorolac tromethamine $0.4 \%$ ophthalmic solution in post-photorefractive keratectomy patients. J Cataract Refract Surg. 2004;30(8):1653-1660.

29. Attar M, Schiffman R, Borbridge L, Farnes Q, Welty D. Ocular pharmacokinetics of $0.45 \%$ ketorolac tromethamine. Clin Ophthalmol. 2010; 4:1403-1408.

30. Waterbury LD, Galindo D, Villanueva L, et al. Ocular penetration and anti-inflammatory activity of ketorolac $0.45 \%$ and bromfenac $0.09 \%$ against lipopolysaccharide-induced inflammation. J Ocul Pharmacol Ther. 2011;27(2):173-178.

31. Gamache DA, Graff G, Brady MT, Spellman JM, Yanni JM. Nepafenac, a unique nonsteroidal prodrug with potential utility in the treatment of trauma-induced ocular inflammation: I. Assessment of antiinflammatory efficacy. Inflammation. 2000;24(4):357-370.

32. Waterbury LD, Silliman D, Jolas T. Comparison of cyclooxygenase inhibitory activity and ocular anti-inflammatory effects of ketorolac tromethamine and bromfenac sodium. Curr Med Res Opin. 2006;22(6): $1133-1140$
33. Nordstrom BL, Friedman DS, Mozaffari E, et al. Persistence and adherence with topical glaucoma therapy. Am J Ophthalmol. 2005; 140(4):598-606.

34. Flach AJ, Kraff MC, Sanders DR, Tanenbaum L. The quantitative effect of $0.5 \%$ ketorolac tromethamine solution and $0.1 \%$ dexamethasone sodium phosphate solution on postsurgical blood-aqueous barrier. Arch Ophthalmol. 1988;106(4):480-483.

35. McGhee CN, Watson DG, Midgley JM, Noble MJ, Dutton GN, Fern AI. Penetration of synthetic corticosteroids into human aqueous humour. Eye. 1994;4(Pt 3):526-530.

36. Samudre SS, Lattanzio FA Jr, Williams PB, Sheppard JD Jr. Comparison of topical steroids for acute anterior uveitis. J Ocul Pharmacol Ther. 2004;20(6):533-547.

37. Kim SJ, Lo WR, Hubbard GB 3rd, et al. Topical ketorolac in vitreoretinal surgery : A prospective, randomized, placebo-controlled, double-masked trial. Arch Ophthalmol. 2008;126(9):1203-1208.

38. Rabiah PK, Fiscella RG, Tessler HH. Intraocular penetration of periocular ketorolac and efficacy in experimental uveitis. Invest Ophthalmol Vis Sci. 1996;37(4):613-618.

39. Heier JS, Awh CC, Busbee BG, et al. Vitreous nonsteroidal antiinflammatory drug concentrations and prostaglandins $\mathrm{E}_{2}$ levels in vitrectomy patients treated with ketorolac $0.4 \%$, bromfenac $0.09 \%$, and nepafenac 0.1\%. Retina. 2009;29(9):1310-1313.

40. Rezaei KA, Toma HS, Cai J, Penn JS, Sternberg P, Kim SJ. Reduced choroidal neovascular membrane formation in cyclooxygenase-2 deficient mice. Invest Ophthalmol Vis Sci. 2011;52(2):701-707.

41. Chin MS, Nagineni CN, Hooper LC, Detrick B, Hooks JJ. Cyclooxygenase-2 gene expression and regulation in human retinal pigment epithelial cells. Invest Ophthalmol Vis Sci. 2001;42(10): 2338-2346.

42. Maloney SC, Fernandes BF, Castiglione E, et al. Expression of cyclooxygenase- 2 in choroidal neovascular membranes from age-related macular degeneration patients. Retina. 2009;29(2):176-180.

43. Kim SJ, Toma HS. Inhibition of choroidal neovascularization by intravitreal ketorolac. Arch Ophthalmol. 2010;128(5):596-600.

44. Baklayan GA, Patterson HM, Song CK, et al. 24-hour evaluation of the ocular distribution of (14)C-labeled bromfenac following topical instillation into the eyes of New Zealand white rabbits. J Ocul Pharmacol Ther. 2008;24(4):392-398.

45. Kim SJ, Toma HS, Barnett JM, Penn JS. Ketorolac inhibits choroidal neovascularization by suppression of retinal VEGF. Exp Eye Res. 2010; 91(4):537-543
Clinical Ophthalmology

\section{Publish your work in this journal}

Clinical Ophthalmology is an international, peer-reviewed journal covering all subspecialties within ophthalmology. Key topics include: Optometry; Visual science; Pharmacology and drug therapy in eye diseases; Basic Sciences; Primary and Secondary eye care; Patient Safety and Quality of Care Improvements. This journal is indexed on Submit your manuscript here: http://www.dovepress.com/clinical-ophthalmology-journal

\section{Dovepress}

PubMed Central and CAS, and is the official journal of The Society of Clinical Ophthalmology (SCO). The manuscript management system is completely online and includes a very quick and fair peer-review system, which is all easy to use. Visit http://www.dovepress.com/ testimonials.php to read real quotes from published authors. 